\title{
Antalya İli İçme Suyu Kaynaklarının Hidrojeokimyasal Özellikleri ve Sağlık Risk Değerlendirmesi
}

\author{
Şehnaz ŞENER ${ }^{\mathbb{D} 1 *}$, Sıla BEKTAŞ ${ }^{\mathbb{D}} 2$ \\ ${ }^{1}$ Süleyman Demirel Üniversitesi, Mühendislik Fakültesi, Isparta \\ ${ }^{2}$ Süleyman Demirel Üniversitesi, Fen Bilimleri Enstitüsü, Isparta \\ Geliş Tarihi (Received): 28.06.2021, Kabul Tarihi (Accepted): 02.09.2021 \\ $\square$ Sorumlu Yazar (Corresponding author ${ }^{*}$ ): sehnazsener@sdu.edu.tr \\ (C) +902462111332 骂 +902462370431
}

ÖZ

Bu çalışmada, Antalya ili içme suyu kaynaklarının hidrojeokimyasal özellikleri incelenerek, sağlık risk değerlendirmesi gerçekleştirilmiştir. Bölgedeki pompa istasyonları ve kaynaklardan Mayıs (2020) ve Ekim (2020) aylarında alınan su örneklerine ait analiz sonuçları kullanılarak suların hidrojeokimyasal özellikleri, kullanılabilirlikleri ve kalite durumları incelenmiştir. Bölgedeki sular $\mathrm{Ca}-\mathrm{CO}_{3}$ ve $\mathrm{Ca}-\mathrm{Mg}-\mathrm{HCO}_{3}$ 'lü sular sınıfındadır. Suların analiz sonuçları TS-266 (2005) ve WHO (2011) tarafından belirtilen içme suyu limit değerleriyle karşılaştırılmıştır. TS-266'ya göre suların genel olarak içilebilir özellikte olduğu belirlenmiştir. Ancak, suların Mg, $\mathrm{HCO}_{3}$ ve TDS değerleri bakımından WHO (2011) limit değerlerini aştığı görülmektedir. Suların sağlık risk değerlendirmesini yapmak ve insan sağığına etkilerini belirlemek için USEPA tarafından geliştirilen "Sağlık riski değerlendirme yöntemi" kullanıımıştır. Çalışma alanındaki suların insan sağlığı açısından ciddi boyutta risk taşımadığı ancak depolardan alınan suların As içeriklerinin kısmen yüksek olduğu belirlenmiştir. Ayrıca, bu suların özellikle çocuklar tarafından tüketilmesi önerilmemektedir.

Anahtar Kelimeler: Antalya, hidrojeokimya, içme suyu, sağlık risk değerlendirmesi

\section{Hydrogeochemical Properties and Health Risk Asessment of Drinking Water Sources in Antalya Province, Turkey}

\begin{abstract}
In this study, hydrogeochemical properties of drinking water resources of Antalya province were examined and health risk assessment was performed. The hydrogeochemical properties, usability and quality status of the waters were examined using the analysis results of drinking water taken from pump stations and springs in May (2020) and October (2020). The waters in the region are $\mathrm{Ca}-\mathrm{CO}_{3}$ and $\mathrm{Ca}-\mathrm{Mg}-\mathrm{HCO}_{3}$ waters. The analysis results of the waters were compared with the drinking water limit values determined by TS-266 (2005) and WHO (2011). According to TS-266, it has been determined that the waters are generally drinkable. However, it was determined that the waters exceeded the WHO (2011) limit values in terms of $\mathrm{Mg}, \mathrm{HCO}_{3}$ and TDS values. The "Health risk assessment method" developed by USEPA was used to assess the health risk of the waters and determine their effects on human health. It has been determined that the waters in the study area do not pose a serious risk for human health, but the As content of the waters taken from the tanks is partially high. In addition, it is not recommended to consume these waters, especially by children.
\end{abstract}

Keywords: Antalya, hydrogeochemistry, drinking water, health risk assessment 


\section{GíRiş}

Günümüzde su kaynaklarının plansız kullanımları, kirlilik, nüfus artışı ile suya olan talebin artması, iklim değişiklikleri ve küresel ısınmanın etkisiyle mevcut su kaynaklarının miktar ve kalite açısından korunması ve iyileştirilmesi oldukça önemli hale gelmiştir (Ji ve ark., 2020; Sohrabi ve ark., 2020; Zhang ve ark., 2020). Suyun dünya üzerindeki dağılımı dikkate alındığında kullanıma en kolay kazandırılabilecek yüzey sularının miktarının oldukça düşük olduğu görülmektedir. Bununla birlikte, kirleticilerden daha kolay etkilenen yüzey sularının kullanımı giderek sınırlanmaktadır (Amiri ve ark., 2021). Bu durumda su ihtiyacının karşılanmasında yeraltısuları daha yoğun kullanılmaya başlanmıştır. Sınırsız bir doğal kaynak olmayan yeraltısularının sürdürülebilir kullanımını sağlayabilmek için hem nicelik hem de nitelik açısından akılcı bir yönetime intiyaç vardır.

Su kaynaklarının kalitesini etkileyen en önemli kirleticilerden biri atık sulardır. Az gelişmiş ve gelişmekte olan ülkelerde evsel atık sularının \%95'iyle endüstriyel atık sularının\%70'i arıtılmadan alıcı ortamlara deşarj edilmektedir. Bunun sonucunda temiz su kaynakları kirlenmekte ve insanlar için içme suyu temin etmek büyük bir problem teşkil etmektedir. (Boateng ve ark., 2019; Ustaoğlu ve ark., 2021). Su kaynaklarının miktarlarında ve kalitelerinde yaşanan ve yaşanması beklenen olumsuz süreçler için var olan su kaynaklarının daha planlı kullanılması içme suyu kaynakları başta olmak üzere tüm su kaynaklarının kalitelerinin korunması, su tüketimlerinin azaltılmasına yönelik çalışmalar ve suların sağlığa etkilerinin belirlenmesi son derece önemlidir.

Bu çalışmada, Antalya ili içme suyu kaynaklarının hidrojeokimyasal özellikleri incelenerek su kaynaklarının içme ve sulama suyu olarak kullanılabilirliğinin araştırılması, sağlık risk değerlendirmesi yapılması ve sağlığa etkisinin ortaya konulması amaçlanmıştır. Bu kapsamda, içme suyu alınan bölgede incelemeler yapılarak, içme ve sulama suyu olarak kullanılan kaynakların mevcut durumu ve sürdürülebilir kullanımına yönelik gerekli incelemeler yapılmıştır.

\section{MATERYAL VE YÖNTEM}

Antalya ili Merkez'e bağlı ilçeleri (Muratpaşa, Döşemealtı, Aksu, Kepez, Konyaaltı) için içme, sulama ve kullanma suyunun \%99'u yeraltısuyu kuyularından, \% 1'i ise kaynaklardan temin edilmektedir. Bölgede içme suyu ihtiyacı Duraliler Pompa İstasyonu, Termessos Pompa İstasyonu, Boğaçay Pompa İstasyonu, Gürkavak Kaynağı ve Yemişpınarı Kaynağı'ndan karşılanmaktadır. Araştırma doğrultusunda çalışma alanı bu istasyonları kapsayacak şekilde belirlenmiş ve Şekil 1'de sunulmuştur. 


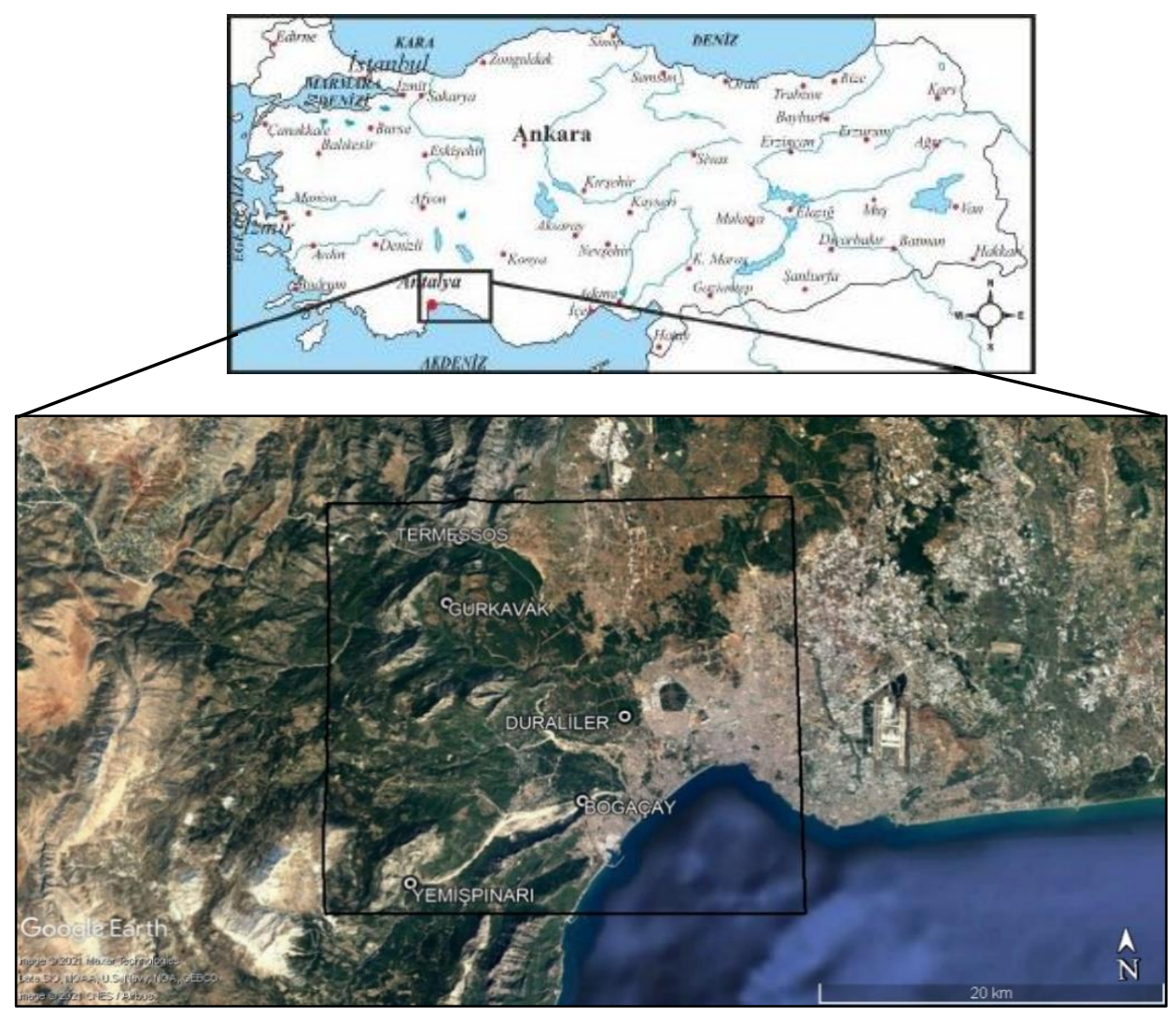

Şekil 1. Çalışma alanı yer bulduru haritası

Öncelikle çalışma alanının jeolojik özellikleri incelenmiş bölgede daha önce yapılan jeolojik ve litolojik araştırmalardan faydalanılarak bölgenin jeolojik yapısı ve jeolojik birimlerin hidrojeolojik özellikleri ortaya konulmuştur. Çaışma alanında içme suyu olarak kullanılan suların kimyasal yapısı, kalite ve sağlık riskinin belirlenmesi amacıyla mevcut durumdaki yağışı ıe kurak dönemleri temsilen Mayıs (2020) ve Ekim (2020) aylarında alınan içme suyu örneklerine ait ölçüm ve analiz sonuçları Antalya Büyükşehir Belediyesi ASAT Genel Müdürlüğü'nden temin edilmiştir. Su örneklerinin major anyon $\left(\mathrm{SO}_{4}{ }^{-2}, \mathrm{Cl}^{-}\right.$, $\left.\mathrm{HCO}_{3}{ }^{-}, \mathrm{CO}_{3}{ }^{-2}\right)$ ve katyon $\left(\mathrm{Ca}^{+2}, \mathrm{Mg}^{+2}, \mathrm{Na}^{+}, \mathrm{K}^{+}\right.$, ) analiz sonuçları ve $\mathrm{pH}$, sıcaklık, elektriksel iletkenli (EC), TDS ve sertlik ölçüm sonuçları farklı diyagramlar ve haritalar üzerinde yorumlanmıştır. Suların içme suyu kullanımı yanı sıra tarımsal sulamada da kullanılması sebebiyle sulama suyu kullanılabilirliği incelenmiştir. Bu kapsamda, su örneklerinin Sodyum iyon yüzdesi ( $\% \mathrm{Na}$ ), Sodyum Adsorbsiyon Oranı (SAR), Özgül Elektriksel Illetkenlik (EC), Artıksal Sodyum Karbonat (RSC), Magnezyum Tehlikesi (MT), Geçirgenlik İndeksi (PI) ve Kelley İndeksi (KI) değerleri hesaplanmıştır. Ayrıca, Wilcox ve ABD Tuzluluk Laboratuvarı Diyagramları hazırlanmıştır.
Bölgede içme suyu olarak kullanılan suların insan sağlığına etkilerinin değerlendirilmesi için Birleşik Devletler Çevre Koruma Ajansı (USEPA) tarafından geliştirilen "Sağlık Risk Değerlendirmesi" yöntemi kullanılmıştır. USEPA (1986) tarafından hazırlanmış olan "Kimyasal Karışımların Sağlık Risk Değerlendirmesi Kılavuzları" birçok kimyasalın sebep olabileceği Kanserojen olmayan etkilerin insan üzerindeki etkilerini belirlemeye yönelik geliştirilen tehlike indeksi $(\mathrm{HI})$ yaklaşımı olup bu çalışmada da bu yöntemler kullanılmıştır. Bir insanın 1 gün boyunca maruz kalacağı doz miktarı olan Yaşam Boyu Ortalama Günlük Doz (ADD) maruziyet hesabı USEPA (2005)'nın önerdiği şekilde yapılmıştır. Oral yolla günlük alınan kimyasal dozu (ADD) Eşitlik 1 yardımıyla hesaplanmaktadır (USEPA, 2004).

$$
\text { ADDoral }=(C i \times L \times E F \times E D) /(B W \times A T)
$$

Formülde;

- $\mathrm{Ci}$ : İçme suyundaki bir (i) kirleticinin konsantrasyonu (mg/l),

- L: Günlük oral yolla alım oranı (l/gün),

- EF: Maruz kalma sıklığı (gün/yıl),

- ED: Maruz kalma süresi (yıl; (30 yıl: kanserojen olmayan risk, 70 yıl: kansorejen risk), 
- BW: İnsan vücut ağırlığı (kg),

- AT: ortalama maruz kalma zamanı (gün, kanserojen olmayan risk için 30 yıl x 365 gün/yıl, kansorejen olan için 70 yıl x 365 gün/yıl),

USEPA (2001) tarafından ADD değerinin hesaplanmasında kullanılan parametrelere ait önerilen değerler kullanılarak ADDoral değeri hesaplanmış ve belirlenen bu etkinin kanserojenik ve/veya kanserojenik olmayan etki ayrımları yapılmıştır. Tehlike katsayısı (HQ) kanserojen olmayan etkileri belirleyen bir katsayı olup Eşitlik 2'deki formül kullanılarak hesaplanmaktadır. Referans doz (RfD) olan inorganik element için kullanılacak değer USEPA tarafından tavsiye edildiği şekilde kullanılmıştır.

$$
\text { Tehlike katsayısı }(H Q)=A D D / R f D
$$

Bu eşitlik ile belirlenen Tehlike katsayısı (HQ) değeri >1 ise kanserojen olmayan etkiler için risk olduğunu göstermektedir. HQ değeri arttıkça insan üzerindeki kanserojen olmayan etki olasılığı artmaktadır (USEPA 1989).HQ değeri sağlık risk değerlendirmesinde belirli bir inorganik elemente yönelik tek başına bir gösterge olabilir. Aynı şekilde, birden fazla element için hesaplanan $\mathrm{HQ}$ değerlerinin toplamı olarak ifade edilen tehlike indeksi $(\mathrm{HI})$ sağlık risk değerlendirmesinde kullanılabilir. Benzer şekilde $\mathrm{HI}$ için de sınır değer 1 olup 1'den büyük değerler insan sağlığı için tehlikeli kabul edilmektedir (USEPA 2001; USEPA, 2004). Sağlık risk değerlendirmesi yapılan su kaynağının bir birey tarafından ömür boyu kullanılması durumuna karşılaşılması muhtemel kanser riski ise aşağıda verilen Eşitlik 3 ile hesaplanmaktadır. Kanser risk (Rc) değeri için limit tolere/kabul edilebilir değerler olarak $10^{-6}$ ile $10^{-4}$ arası belirtilmektedir (Li ve Zhang, 2010).

$$
\text { Kanser risk }(\mathrm{Rc})=\mathrm{ADD} \times \mathrm{SF}
$$

Formülde;

- SF: eğim faktörü (mg/kg/gün);

- ADD: kronik günlük alım miktarı (mg/kg/gün).

Eğim faktörü (SF) katsayısı belirli bir kirleticinin (inorganik element) yol açacağı potansiyel kanser riskinin değerlendirilmesinde kullanılmaktadır (USEPA, 1989). ÇaIışmada kullanılan SF ve RfD değerleri EPA Entegre Risk Bilgi Sistemi ve EPA tarafından hazırlanmış olan Sağlık Etkileri Değerlendirme tablolarından sağlanmıştır (IRIS, 2005).

\section{BULGULAR VE TARTIŞMA}

\section{Jeoloji ve Hidrojeoloji}

Çalışma alanı ve yakın çevresinde yer alan temel birimleri otokton kayaç birlikleri oluşturmakta olup bu birimler Palosen-Kretase yaşı kireçtaşı-dolomitik kireçtaşlarından oluşan Beydağları Otoktonu içerinde yaralan formasyonlardır. Çalışma alanında Beydağları Formasyonu (Kb), Tekkeköy Üyesi (Kbt), Çamlıdere Olistrostromu (Tpç), Söbütepe Formasyonu (Tpes), Beydağları otokton birimlerini oluşturmaktadır. Allokton birimler ise Antalya nap birimleri olup çalışma alanında geniş alanlarda gözlenmektedir. Keçili Formasyonu (Kk), Kırkdirek Formasyonu (Kkm), Yeniceboğazıdere Formasyonu (Jky), Harzburjit (Ktoh), Tekedağı Formasyonu (Jkt), Tilkideliğitepe Formasyonu (TRt), Gökdere Formasyonu (TRag), Çandır Formasyonu (TRac), Karadere Formasyonu (TRak), Tesbihli Formasyonu (Trat), Alakırçay Grubu (TRa), Kesmeköprü Formasyonu (TRke) ve Dinek Formasyonu $(\mathrm{Pd})$ bölgedeki allokton birimlerdir. Otokton konumlu örtü kayaçları olarak ise Antalya travertenleri (Qa), yamaç molozu (Qym), alüvyon yelpazesi (Qay) ve alüvyon (Qal) haritalanmıştır.Bölgenin jeolojisini ortaya koymak amacıyla çalışma alanının bulunduğu bölge topoğrafik haritalar üzerinde belirlenip, daha önce bölgede yapılan çalışmalar ve arazi çalışmalarından yararlanılarak 1/100.000 ölçekte bölgenin jeoloji haritası hazırlanmıştır (Şekil 2). Çalışma alanında Kargılı'nın batısında yer alan ve harita üzerinde 'Kb' olarak karakterize edilen Beydağları Formasyonu Jura-Kretase yaşlı neritik kireçtaşlarından oluşmuş ve Günay ve ark. (1982) tarafından adlandırılmıştır. Krem, bej gibi renklerde gözlenen birim orta-kalın tabakalı, neritik kireçtaşlarından oluşmaktadır. Tabanında bazen dolomitleşme yaygın olarak gözlenebilmektedir. Sık erime boşluklu olan Beydağları formasyonunda karstlaşma yaygın olarak gözlenmektedir. Korkuteli ilçesine doğru uzanan birimin kalınlığının 3000 metreye kadar ulaştığı bilinmektedir (Poisson, 1977; Günay ve ark., 1982). Jeolojik harita üzerinde 'Kbt' olarak karakterize edilen Tekkeköy üyesi birimi Şenel ve ark., (1989) tarafından adlandırılmıştır. Birimin genel olarak Globotruncanalı mikritlerden oluştuğu bilinmektedir. Çalışma alanının kuzeyinde yer alan birim, ince-orta tabakalı, bej, krem, gri, kirli sarı vb. renklerde yer yer bol Globotruncanalı, bazen çört yumrulu kireçtaşlarından oluşmaktadır. Birimin üstte Çamlıdere olitostromu ile geçişli olduğu bilinmektedir. Bölgede yer alan 'Tpç' olarak karakterize edilen birim Poisson (1977) tarafından Çamlıdere Olistostromu olarak adlandırılmıştır. Formasyon tabanında ince-orta tabakalı, bej, krem, gri, yeşilimsi, pembe vb. renklerde killi kireçtaşı, marn, kiltaşı, silttaşı, kalkarenit, kumtaşlarından oluşmaktadır. Üstte ise Antalya napları ve Beydağları for- 
masyonundan türemiş olistolitli kırıntılara rastlanmaktadır. Kırıntıların matriksi bazen kumtaşı-kiltaşı, bazen ise konglomera olarak görülmektedir. Çamlıdere olistostromu Antalya napları ile tektonik ilişki gösterir. Antalya naplarının yerleşimine bağlı olarak, aktif havza ortamında çökeldiği bilinen birim Daniyen yaşlı kabul edilir.

Söbütepe formasyonu (Tpes) Yalçınkaya ve ark. (1986) tarafından adlandırılmıştır. Beydağları formasyonu üzerine transgresif olarak gelen, Üst Paleosen-Alt Eosen yaşı bu formasyon kireçtaşı, kumtaşı vb. kaya türlerinden oluşmaktadır (Şenel, 1997b). Formasyon, litolojik özellikleri nedeniyle karstik şekillenmeye elverişli değildir. Bu nedenle, çoğunlukla karstlaşma açısından taban seviyesini oluşturmaktadır (Koçak ve Arıbaş, 2003). Poisson (1977) tarafından adlandırılan Antalya Travertenleri kahve-sarı renkli, primer ve sekonder kökenli karstik erime yapıları içermektedir. Travertenler, yaklaşık $299 \mathrm{~m}$ zemin kotunda Beydağları Formasyonundan tahliye olan kalsiyum bikarbonatça zengin karst sularının kontrolsüz akış dönemlerinde az eğilimli ve kısmen geçirimli tabandan akarken çökelttiği ikinci karbonatlar olarak değerlendirilmektedir (Özüş, 1992). Birimin kronolojik yaşı seyrek de olsa içerdiği Condora sp. bulgusuna (Akay ve ark., 1985) dayanılarak Üst Pliyosen - Kuvaterner olarak kabul edilmiştir (Özüş, 1992). Yamaç Molozu (Qym), Alüvyon Yelpazesi (Qay) ve Alüvyon (Qal) olarak karakterize edilen birimlerin ise atmosferik koşullarda Kuvaterner yaşlı oluştuğu düzensiz yığışımlar halinde blok çakıl ve çamur birikintilerinden meydana geldiği bilinmektedir. Bölgede yer alan allokton birimleri kapsayan Antalya Naplarının okyanusal kabuk, havza, yamaç ve platform tipli olduğu Antalya il merkezinin kuzey ve kuzeybatısında yüzeylendiği görülmektedir. Antalya napları, OrtaÜst Triyas yaşı, ince-orta tabakalı kumtaşı, şeyl, çamurtaşı, kireçtaşı, radyolarit, çört ve serpantinlerden oluşan bir karmaşıktan meydana gelmektedir (Karagüzel, ve ark., 2006). Antalya Naplarını kapsayan birimler yaşıdan gence doğru, Kesmeköprü Formasyonu (TRke), Tesbihli Formasyonu (Trat), Karadere Formasyonu (TRak), Çandır Formasyonu (TRac), Gökdere Formasyonu (TRag), Alakırçay Grubu (TRa) Tilkideliğitepe Formasyonu (TRt), Yeniceboğazıdere Formasyonu (Jky), Tekedağı Formasyonu (Jkt), Harzburjit (Ktoh) Kırkdirek Formasyonu (Kkm), Keçili Formasyonu (Kk) olarak sıralanabilir. Birimler genellikle uyumlu olarak üzerlenirken Tilkideliğitepe Formasyonu Alakırçay grubu ile tektonik alt ilişkisine sahiptir. (Şenel, 1997c). Ayrıca, Kesmeköprü Formasyonu,Alakırçay grubu tarafından uyumsuz olarak örtülmektedir. Jeolojik harita üzerinde 'Pd' olarak karakterize edilen Dinek Formasyonu Kalafatçıoğlu (1973) tarafından adlandırıımış olup, yer yer ince tabakalı, koyu renkli ve bol fosilli, sık çatlaklı, Mizzialı kireçtaşlarını temsil etmektedir. Üst seviyelerinde dolomi- tik kireçtaşları görülen birim tektonik tabanlıdır. Uyumsuz olarak Kesmeköprü Formasyonu tarafından örtülmektedir.

Çalışma alanındaki su noktaları araştırıııken her bir litolojik birimin akifer olabilme özellikleri değerlendirilerek akiferlerin tanımlaması yapılmış ve çalışma alanının hidrojeoloji haritası oluşturulmuştur (Şekil 3). Çalışma alanında gözlenen jeolojik birimler litolojik özelliklerine ve yeraltısuyu bulundurma kapasitelerine göre Taneli Ortam Akiferi, Karstik Akifer, Yarı Geçirimli Birim ve Geçirimsiz Birim olarak sınıflandırılmıştır. Çalışma alanında bulunan Alüvyon (Qal), Alüvyon Yelpaze (Qay) ve Yamaç molozu (Qym) birimleri "taneli ortam akiferi" olarak sınıflandırılmıştır. Bu birimler içerdikleri çakıl, kum, kil, silt gibi tutturulmamış ve kırıntılı malzemeler arasındaki gözeneklerde önemli miktarlarda yeraltısuyu bulundurmaktadırlar. Çalışma alanında su üretimi yapılan sondaj kuyularının büyük bir kısmı da taneli ortam akiferi olarak tanımlanan bölgelerde bulunmaktadır. Özellikle akarsu yataklarına yakın alanlarda kum - çakıl oranları daha yüksek olup buna bağlı olarak gözeneklilik ve geçirgenlik daha yüksektir. Çalışma alanında alüvyonun kalınlığı 0110 m arasındadır. Mevcut sondaj kuyularında ölçülmüş olan yeraltısuyu derinlikleri ise 2-32 $\mathrm{m}$ arasında değişmektedir. Ayrıca, akifer permeabilitesinin 24,04 m/gün ile 244,63 m/gün arasında olduğu belirlenmiştir (DSi, 2017a, b). Çalışma alanında bulunan, Antalya travertenleri (Qa), Tekedağı Formasyonu (JKt), Gökdere Formasyonu (Trag), Dinek Formasyonu (Pd) ve Beydağları Formasyonu (Kb) ve Tekkeköy Üyesi (Kbt) "Karstik Akifer" olarak sınıflandırılmıştır. Karstik akiferler, kireçtaşı, dolomit ve benzeri karbonat kayalardan oluşmaktadır. Özellikle çalışma alanının doğusunda geniş yayılıma sahip olan travertenler önemli miktarda yeraltısuyu bulundurmaktadır. Ayrıca, diğer bölgelerde yüzeyleyen kireçtaşı ve dolomit birimlerden yüksek debili kaynak çıkışları ve sondajlar vasıtasıyla yeraltısuyu alınmaktadır. Bölgede karstik akifer olarak tanımlanan kireçtaşlarının kaIınlığı yer yer değişkenlik göstermektedir. Traverten birimlerde açılmış olan sondaj kuyusu verilerine göre traverten karstik akiferinin ortalama kalınlığı 38 m'dir. Kuyularda ölçülen yeraltısuyu seviyesi ise $18 \mathrm{~m}$ ile $38 \mathrm{~m}$ arasında değişmektedir. Ortamın yaklaşık permeabilitesi ise $86.45 \mathrm{~m} / g u ̈ n$ olarak belirlenmiştir (DSi, 2017b). ÇaIışma alanında yüzeyleyen Keçili formasyonu (Kk), Yeniceboğazıdere formasyonu (JKy), Tilkideliğitepe formasyonu (TRt) ve Söbütepe Formasyonu (TPes) benzer litolojik ve hidrojeolojik özelliklere sahip olmaları sebebiyle "Yarı Geçirimli Birim (Gçy)" olarak sınıflandırılmıştır. Genel olarak, kumtaşı, kiltaşı ve silttaşı vb. kaya birimlerinden oluşan formasyonlar ve mikrit, killi-kumlu mikrit ara seviyeli kumtaşı ve konglomeralardan oluşan formasyonlar içerisindeki kiltaşı seviyeleri bu birimlerin 
Antalya İli İçme Suyu Kaynaklarının Hidrojeokimyasal Özellikleri ve Sağlık Risk Değerlendirmesi

akifer olma özelliğini kısıtlamaktadır. Mikrit, çörtlü mikrit,,kireçtaşı-kalsitürbidit ara seviyeli radyolarit, çört ve şitlerden oluşan Yeniceboğazıdere formasyonu değişik fasiyes özelliği, sahip olduğu kırıklı çatlaklı yapısı ve litolojik özellikleri bakımından bünyesinde kısmen yeraltısuyu bulundurabilir. Ayrıca, yarı geçirim olarak sınıflandırılan diğer formasyonlar da içerisindeki kireçtaşı sevi- yelerinin yeraltısuyu bulundurabilme özelliklerinden dolayı yarı geçirimli birim olarak değerlendirilmişlerdir. ÇaIışma alanında bulunan Harzburjit (Ktoh), Kırkdirek formasyonu (Kkm), Çandır (TRac), Tesbihli (TRat), Kesmeköprü (TRke) ve Karadere (TRak) formasyonları ve Alakırçay Grubu (TRa) ile Çamlıdere Olistostromu (Tpç) ise "Geçirimsiz Birim" olarak sınıflandırılmıştır.

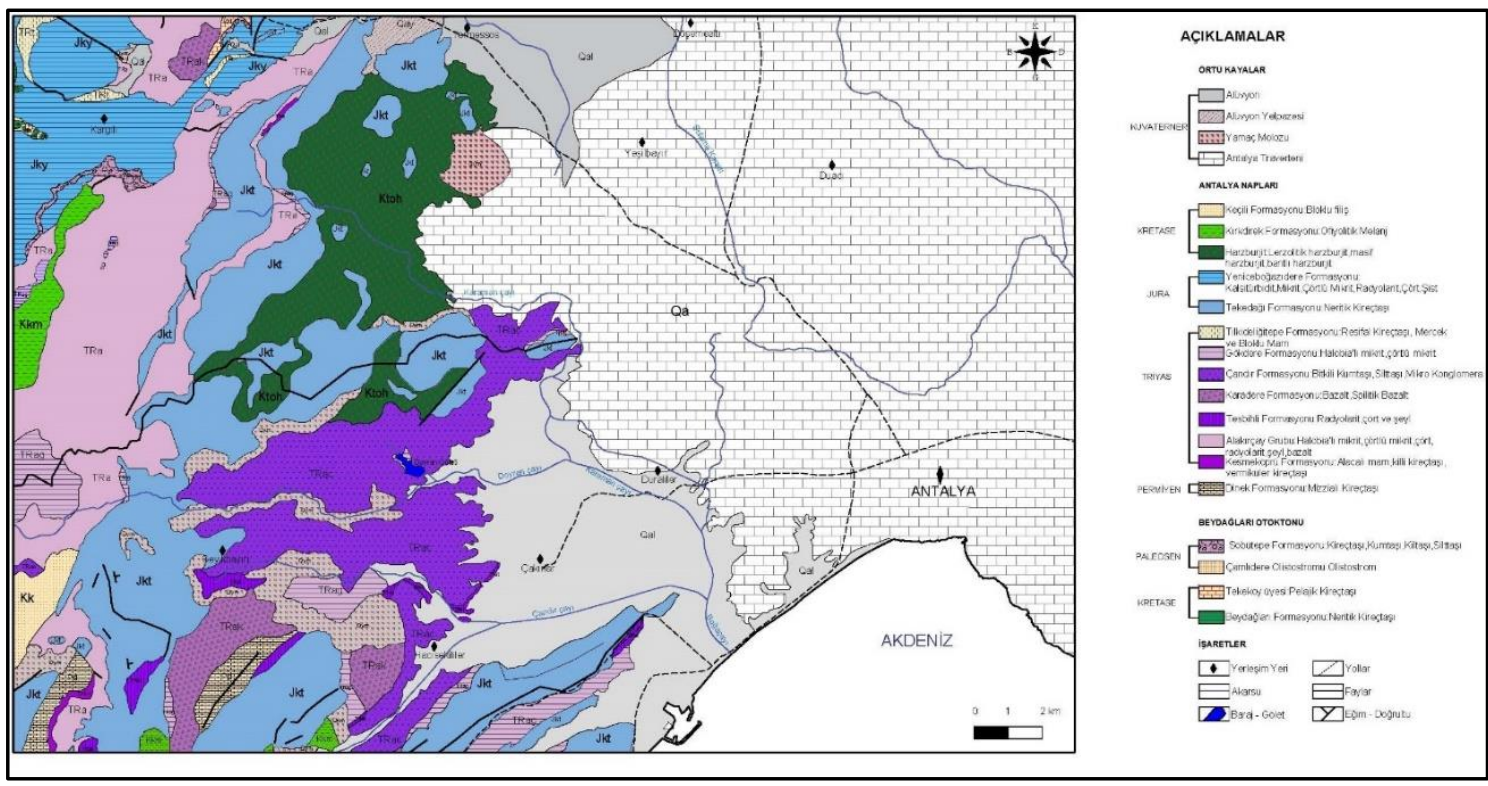

Şekil 2. Çalışma alanının jeoloji haritası (Şenel, 1997 a, b, c'den yararlanılarak.)

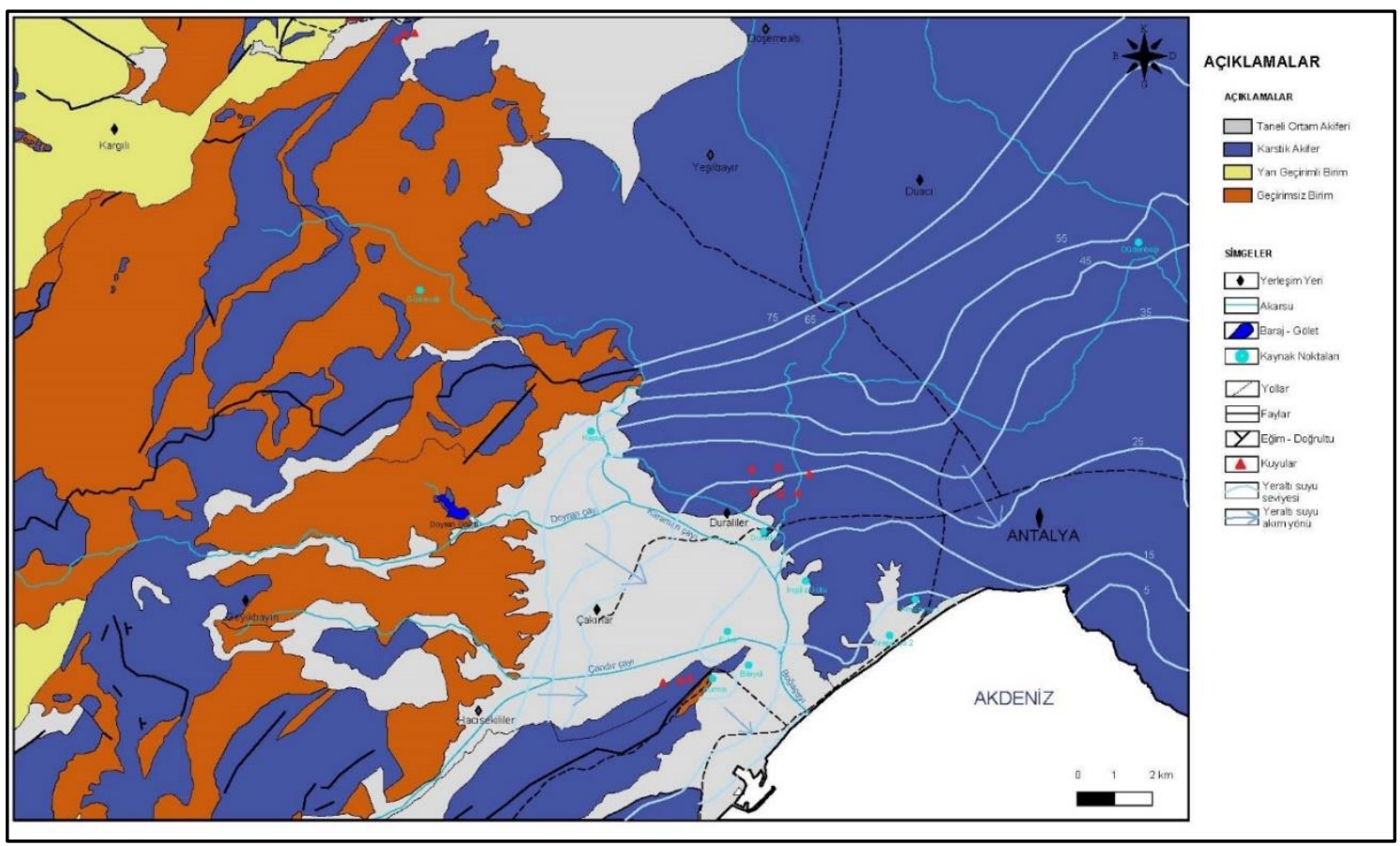

Şekil 3. Çalışma alanının hidrojeoloji haritası 


\section{Hidrojeokimya}

Antalya ili içme suyu kaynaklarının hidrojeokimyasal özelliklerini, kullanım durumunu ve kalitesini belirleyerek sağlık risk değerlendirmesini yapabilmek amacıyla Antalya şehir merkezinde içme suyu kaynağı olarak kullanılan 5 farklı lokasyona ait su örnekleri değerlendirilmiştir. Duraliler 1, Duraliler 2, Boğaçay, Yeniköy-depo ve Yeşilbayır-depo olarak isimlendirilen lokasyonlardan Mayıs (2020) ve Ekim (2020) aylarında alınan içme suyu örneklerine ait ölçüm ve analiz sonuçları Antalya Su ve Atıksu İdaresi Genel Müdürlüğü'nden temin edilmiştir (URL-1, 2021). İçme suyu olarak kullanılan sular kimyasal özelliklerine bağıı olarak kullanım durumları ve insan sağlığına etkisi bakımından incelenmiştir. Antalya iline içme suyu sağlayan lokasyonlardan alınan örneklere ait analiz sonuçları Tablo 1'de sunulmuştur.

Tablo 1. Su örneklerinin hidrojeokimyasal özellikleri

\begin{tabular}{|c|c|c|c|c|c|c|c|c|c|c|c|c|c|c|c|}
\hline Dönem & $\begin{array}{c}\text { Numune } \\
\text { Yeri }\end{array}$ & $\begin{array}{c}\mathrm{Na}+ \\
(\mathrm{mg} / \mathrm{l})\end{array}$ & $\begin{array}{c}\mathrm{K}^{+} \\
(\mathrm{mg} / \mathrm{l})\end{array}$ & $\begin{array}{l}\mathrm{Ca}^{++} \\
(\mathrm{mg} / \mathrm{l})\end{array}$ & $\begin{array}{l}\mathrm{Mg}^{++} \\
(\mathrm{mg} / \mathrm{l})\end{array}$ & $\underset{(\mathrm{mg} / \mathrm{l})}{\mathrm{Cl}^{-}}$ & $\begin{array}{l}\mathrm{SO}_{4}^{-2} \\
(\mathrm{mg} / \mathrm{l})\end{array}$ & $\begin{array}{l}\mathrm{HCO}_{3}^{-} \\
(\mathrm{mg} / \mathrm{l})\end{array}$ & $\begin{array}{l}\text { Sicaklık } \\
\left(C^{0}\right)\end{array}$ & $\begin{array}{l}\text { Sertlik } \\
\left(\mathrm{Fr}^{\circ}\right)\end{array}$ & $\begin{array}{c}E C \\
\mu S / c m\end{array}$ & TDS & $\mathrm{pH}$ & $\% \mathrm{Na}$ & SAR \\
\hline \multirow{5}{*}{$\begin{array}{l}\text { Yağışıı Dö- } \\
\text { nem }\end{array}$} & $\begin{array}{c}\text { Duraliler } 1 \\
\text { (D1) }\end{array}$ & 20,20 & 1,61 & 90,97 & 20,78 & 21,06 & 0,40 & 456,50 & 20 & 31,40 & 616 & 356,42 & 7,09 & 12,27 & 0,50 \\
\hline & $\begin{array}{l}\text { Duraliler } 2 \\
\text { (D2) }\end{array}$ & 20,23 & 1,61 & 89,94 & 20,03 & 21,33 & 0,40 & 461,30 & 20 & 30,83 & 627 & 388,74 & 7,08 & 12,46 & 0,50 \\
\hline & $\begin{array}{c}\text { Boğaçay } \\
\text { (B) }\end{array}$ & 17,60 & 1,15 & 67,93 & 34,06 & 16,15 & 0,40 & 315,20 & 20 & 31,17 & 586 & 351,60 & 7,36 & 11,02 & 0,43 \\
\hline & $\begin{array}{c}\text { Yeniköy } \\
(Y)\end{array}$ & 25,22 & 2,66 & 125,10 & 33,77 & 24,55 & 0,40 & 539,70 & 19 & 45,35 & 842 & 493,41 & 6,84 & 10,80 & 0,52 \\
\hline & $\begin{array}{c}\text { Yeşilbayır } \\
\text { (YŞ) }\end{array}$ & 26,76 & 3,15 & 142,52 & 36,78 & 25,68 & 0,40 & 582,50 & 19 & 50,95 & 901 & 521,32 & 6,81 & 10,19 & 0,52 \\
\hline \multirow{5}{*}{$\begin{array}{l}\text { Kurak Dö- } \\
\text { nem }\end{array}$} & $\begin{array}{c}\text { Duraliler } 1 \\
\text { (D1) }\end{array}$ & 20,80 & 2,06 & 96,40 & 19,79 & 21,93 & 0,40 & 471,50 & 20 & 32,34 & 626 & 362,20 & 7,10 & 12,16 & 0,50 \\
\hline & $\begin{array}{c}\text { Duraliler } 2 \\
\text { (D2) }\end{array}$ & 20,69 & 2,02 & 96,05 & 19,48 & 21,78 & 0,40 & 468,30 & 20 & 32,13 & 625 & 387,50 & 7,11 & 12,24 & 0,50 \\
\hline & $\begin{array}{c}\text { Boğaçay } \\
\text { (B) }\end{array}$ & 17,84 & 1,52 & 73,08 & 34,93 & 16,69 & 0,40 & 352,40 & 21 & 32,82 & 616 & 369,60 & 7,36 & 10,64 & 0,43 \\
\hline & $\begin{array}{c}\text { Yeniköy } \\
(Y)\end{array}$ & 25,70 & 2,96 & 128,04 & 34,11 & 24,89 & 0,40 & 529,70 & 20 & 46,22 & 834 & 488,72 & 6,90 & 10,78 & 0,52 \\
\hline & $\begin{array}{c}\text { Yeşilbayır } \\
(Y S ̧)\end{array}$ & 27,74 & 3,68 & 143,37 & 37,41 & 26,03 & 0,40 & 574,60 & 20 & 51,43 & 905 & 523,63 & 6,82 & 10,49 & 0,53 \\
\hline \multirow{2}{*}{$\begin{array}{l}\text { Yönetmelik } \\
\text { Sınır Değer- } \\
\text { leri (mg/L) }\end{array}$} & $\begin{array}{l}\text { TS-266 } \\
(2005)\end{array}$ & 200 & 12 & 200 & 150 & 250 & 250 & & & & & & $6,5-9,5$ & & \\
\hline & $\begin{array}{l}\text { WHO } \\
\text { (2011) }\end{array}$ & 200 & & 300 & & 250 & 250 & 500 & & & & 500 & $6,5-8,5$ & & \\
\hline
\end{tabular}

Su örneklerine ait analiz sonuçları değerlendirildiğinde su örneklerinin sertlik değerleri 30,83 ile 51,43 arasında değişmektedir. Fransız Sertlik Derecesi' ne göre çalışma alanındaki sular oldukça sert ve sert sular sınıfında yer almaktadır. Su örneklerine ait pH ölçüm sonuçlarına göre suların $\mathrm{pH}$ değerleri 6.81-7.36 arasında olup Yeniköy ve Yeşilbayır istasyonlarından alınan örnekler asidik karakterli, Duraliler 1, Duraliler 2 ve Boğaçay istasyonundan alınan örnekler ise bazik karakterlidir. Suyun içerisindeki çözünmüş iyon miktarının bir göstergesi olan ve sıcaklık ile değişim gösteren özgül elektriksel iletkenlik (EC) değeri su örneklerinde 586 ile $905 \mu \mathrm{S} / \mathrm{cm}$ arasında değişmektedir. Piper diyagramı kullanılarak çaIışma alanındaki suların hidrojeokimyasal özellikleri değerlendirilmiştir. Kurak ve yağışlı dönemlere ait kimyasal analiz sonuçları ayrı ayrı değerlendirilmek üzere diyagram üzerine yerleştirilmiştir. Bu diyagramlara göre, bölgedeki suların $\mathrm{Ca}-\mathrm{CO}_{3}$ ve $\mathrm{Ca}-\mathrm{Mg}-\mathrm{HCO}_{3}$ 'lü sular sınıfında olduğu belirlenmiştir (Şekil 4 ve 5). 
Antalya İli İçme Suyu Kaynaklarının Hidrojeokimyasal Özellikleri ve Sağlık Risk Değerlendirmesi

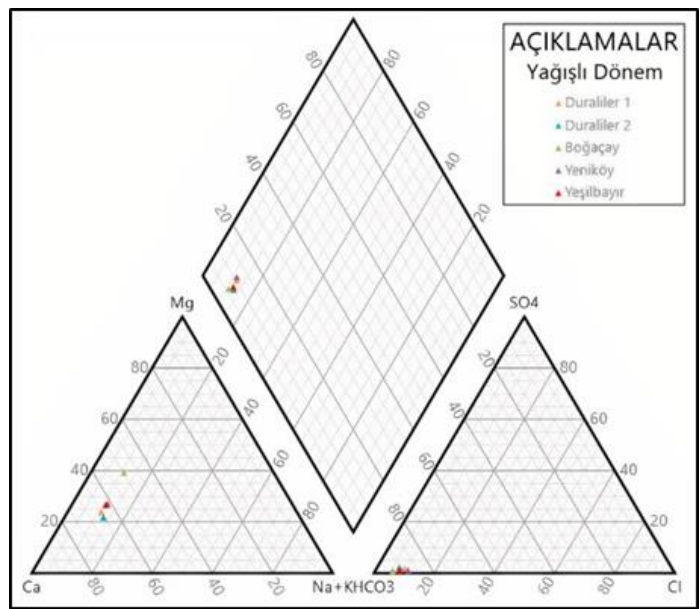

Şekil 4. Piper diyagramı (Mayıs-2020)

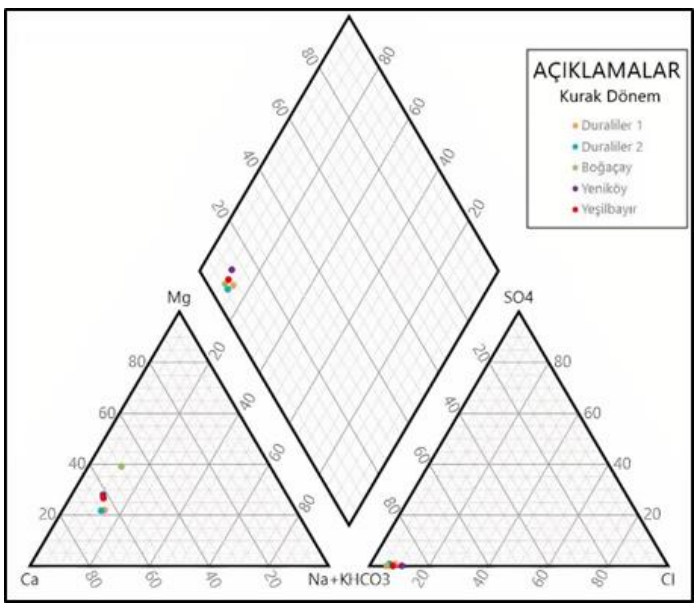

Şekil 5. Piper diyagramı (Ekim-2020)

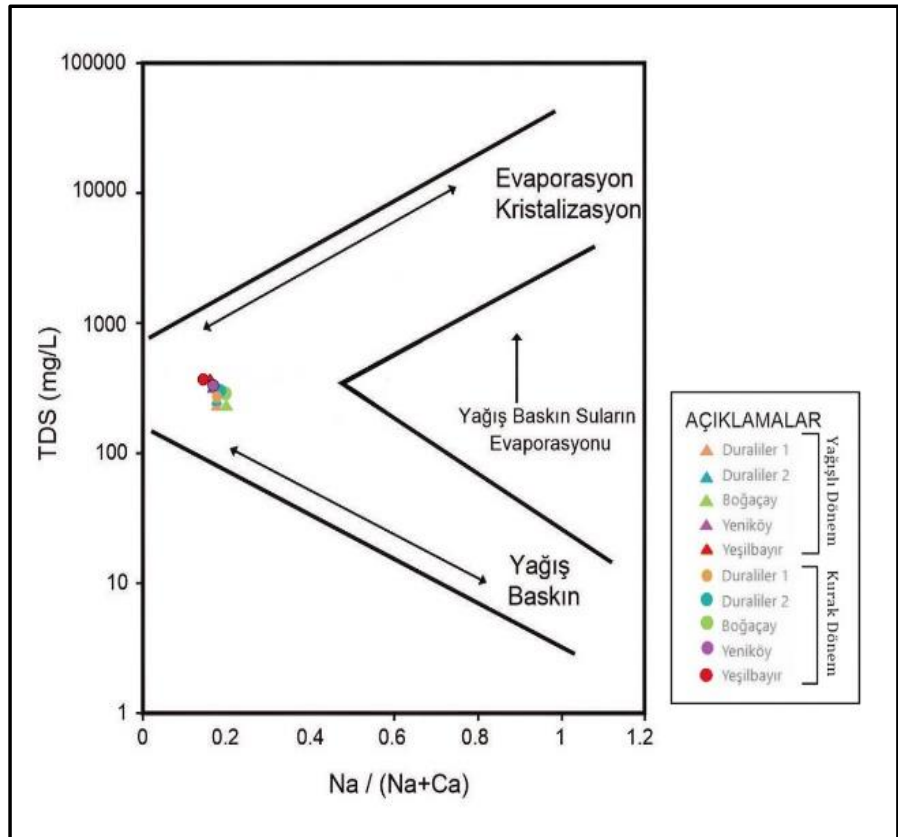

Şekil 6. Gibbs diyagramı (Mayıs/yağışlı -Ekim/kurak -2020)

Çalışma alanındaki su kaynaklarının kimyasal özelliklerinin oluşumunu etkileyen mekanizmaları belirlemek için su örneklerinin iyon konsantrasyonları Gibbs diyagramlarına yerleştirilmiştir. Bu diyagramlarda TDS ve $\mathrm{Na} /$ $(\mathrm{Na}+\mathrm{Ca})$ iyon konsantrasyonları karşıllaştırılmıştır (Gibbs, 1970). Yaygın olarak kullanılan Gibbs diyagramında "yağış baskın", "kayaç baskın" ve "buharlaşma baskın" gibi farklı bölgeler tanımlanmış ve bölgedeki su kimyasını kontrol eden ana mekanizmayı belirlemek için hazırlanan Gibbs diyagramı Şekil 6'da sunulmuştur. Buna göre, incelenen sular "kayaç baskın" bölgesinde yer almaktadır. Bu durum, su kimyasının esas olarak kaya-su etkileşimi sonucunda geliştiğini ve hidrojeokimyasal süreçlerle ilişkili olduğunu göstermektedir.

Tablo 2'de verilmiş olan Schoeller (1955)'e ait sınıflama suları klorür, sülfat ve karbonat içeriklerine göre gruplandırmaktadır. Çalışma kapsamında incelenen suların, Karbonat+bikarbonat değerleri 5.17-9.55 mek/l arasında değişmekte ve Duraliler, Duraliler 2 ve Yeşilbayır istasyonlarından alınan su örnekleri "hiperkarbonatlı sular" sınıfında yer almaktadır. Yeniköy istasyonu kurak dönem verilerine göre sular "olağan karbonatlı sular" sınıfında iken, yağışlı dönem verileri "hiperkarbonatlı sular" sınıfını işaret etmektedir. Boğaçay istasyonundan alınan 
Antalya İli İçme Suyu Kaynaklarının Hidrojeokimyasal Özellikleri ve Sağlık Risk Değerlendirmesi

su örneği ise kurak dönemde "hiperkarbonatlı sular" sınıfında, yağışlı dönemde ise "olağan karbonatlı sular" sınıfında yer almaktadır. Bütün istasyonlar Klorür ve Sülfat konsantrasyonları bakımından "olağan klorürlü" ve "olağan sülfatlı sular" sınıfında yer almaktadır (Tablo 3).

Tablo 2. Schoeller (1955) klorür, sülfat, karbonat-bikarbonat sınıflaması

\begin{tabular}{|c|c|c|}
\hline$\frac{1}{\pi}$ & Su sınıfı & Klorür Miktarı (mek/l) \\
\hline 屴 & Hiperklorürlü Sular & $>700$ \\
\hline$\overline{\bar{~}}$ & Klorotalasik Sular & $420-700$ \\
\hline & Klorürce Zengin Sular & $140-420$ \\
\hline & Orta Klorürlü Sular & $40-140$ \\
\hline & Oligoklorürlü Sular & $15-40$ \\
\hline$\frac{0}{\varepsilon}$ & Olağan Klorürlü Sular & $<15$ \\
\hline 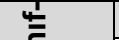 & Su sınıfı & Sülfat Miktarı (mek/l) \\
\hline ڤ̆ & Hiposülfatlı Sular & $>58$ \\
\hline$\pm \bar{\omega}$ & Sülfatlı Sular & $24-58$ \\
\hline & Oligosülfatlı Sular & $6-24$ \\
\hline : & Olağan Sülfatlı Sular & $<6$ \\
\hline$\frac{1}{m} \stackrel{\frac{1}{E}}{\bar{D}}$ & Su sınıfı & $\begin{array}{l}\text { Karbonat+Bikarbonat } \\
\text { Miktarı (mek/l) }\end{array}$ \\
\hline \pm & Hiperkarbonatlı Sular & $>7$ \\
\hline 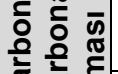 & $\begin{array}{l}\text { Olağan Karbonatlı Su- } \\
\text { lar }\end{array}$ & $2-7$ \\
\hline 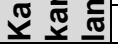 & Hipokarbonatı Sular & $<2$ \\
\hline
\end{tabular}

Tablo 3. Su örneklerinin klorür, sülfat, karbonat- bikarbonat değerleri (mek/l)

\begin{tabular}{|c|c|c|c|c|c|c|}
\hline \multicolumn{7}{|c|}{ Schoeller (1955) (r) } \\
\hline & Duraliler-1 & Duraliler-2 & Boğaçay & Yeniköy & Yeşilbayır & \\
\hline $\mathrm{Cl}$ & 0,59 & 0,60 & 0,46 & 0,69 & 0,72 & \multirow{3}{*}{$\begin{array}{l}\text { Yağışı। } \\
\text { Dönem }\end{array}$} \\
\hline $\mathrm{SO}_{4}{ }^{-2}$ & 0,01 & 0,01 & 0,01 & 0,01 & 0,01 & \\
\hline $\mathrm{CO} 3+\mathrm{HCO}_{3}$ & 7,48 & 7,56 & 5,17 & 8,84 & 9,55 & \\
\hline $\mathrm{Cl}$ & 0,62 & 0,61 & 0,47 & 0,70 & 0,73 & \multirow{3}{*}{$\begin{array}{l}\text { Kurak } \\
\text { Dönem }\end{array}$} \\
\hline $\mathrm{SO}_{4}{ }^{-2}$ & 0,01 & 0,01 & 0,01 & 0,01 & 0,01 & \\
\hline $\mathrm{CO} 3+\mathrm{HCO}_{3}$ & 7,73 & 7,73 & 7,67 & 5,78 & 8,68 & \\
\hline
\end{tabular}

Ülkemizde suların içme suyu olarak kullanılabilirliğini denetleyen kriter ve limit değerler mevzuatta bulunan "Insani Tüketim Amaçlı Sular Hakkındaki Yönetmelik (TS$266,2005)$ )" ve Tarım ve Orman Bakanlığı tarafından hazırlanmış "İçmesuyu Elde Edilen Suların Kalitesi ve Arıtılması Hakkında Yönetmelik" (Resmi Gazete, 2019) ile belirlenmiştir. İçmesuyu Elde Edilen Suların Kalitesi ve Arıtılması Hakkında Yönetmelik, değerlendirilen bütün parametreler için verilen limit değerlere göre $A 1, A 2$ ve A3 olmak üzere üç farklı kategori tanımlamıştır. Bu kategorilere göre sular için arıtma sınıfları ve türleri belirlenmiştir. Çalışma kapsamında Antalya ili içme suyu kaynaklarından alınan örneklerin analiz sonuçları söz konusu yönetmelikler ile belirlenen limit değerler ve Dünya Sağlık Örgütü (WHO, 2011) standart değerleri dikkate alınarak değerlendirilmiştir. İlgili yönetmeliklere ait limit değerler ile su örneklerinin azot türevleri ve ağır metal konsantrasyonlarına ait sonuçlar Tablo 1 ve 4'de verilmiştir. Analiz sonuçlarının TS-266 (2005) ve WHO (2011) tarafından belirtilen limit değerler ile karşılaştırıldığında, su örneklerinin tamamının içme suyu standartlarının limit değerlerine uygun özellikte ve içilebilir özellikte olduğu görülmektedir. Ancak, suların $\mathrm{HCO}_{3}$ ve TDS değerleri bakımından WHO (2011) limit değerlerini aştığı belirlenmiştir. Yeniköy ve Yeşilbayır depolardan alınan örneklerin $\mathrm{HCO}_{3}$ konsantrasyonları, Yeşilbayır deposundan alınan örneklerin ise TDS değerleri limit değerlerin üzerindedir. İçmesuyu Elde Edilen Suların Kalitesi ve Arıtılması Hakkında Yönetmelik ile tanımlanan A1, A2 ve A3 kategorilerinin limit değerleri dikkate alındığında ise su örneklerinin tamamı "A1: Basit fiziksel arıtma ve dezenfeksiyon ardından içilebilir hale gelen sular" kategorisi için verilmiş olan limit değerlerin altında olup fiziksel arıtmaya intiyaç duyulmaksızın içilebilir özelliktedir. 
Antalya İli İçme Suyu Kaynaklarının Hidrojeokimyasal Özellikleri ve Sağlık Risk Değerlendirmesi

Tablo 4. Su örneklerinin ağır metal ve azot türevleri analiz sonuçları

\begin{tabular}{|c|c|c|c|c|c|c|c|c|c|c|c|c|c|c|c|}
\hline \multirow{2}{*}{ Dönem } & \multirow{2}{*}{$\begin{array}{c}\text { Numune } \\
\text { Yeri }\end{array}$} & Al & $\mathbf{M n}$ & $\mathrm{Cu}$ & $\mathrm{Pb}$ & $\mathrm{Hg}$ & Cd & $\mathrm{Se}$ & As & $\mathrm{Fe}$ & $\mathrm{Cr}$ & $\mathrm{Ni}$ & $\mathrm{NO}_{2}$ & $\mathrm{NO}_{3}$ & $\mathrm{NH}_{4}$ \\
\hline & & $\mu \mathrm{g} / \mathrm{l}$ & $\mu \mathrm{g} / \mathrm{l}$ & $\mu \mathrm{g} / \mathrm{l}$ & $\mu \mathrm{g} / \mathrm{l}$ & $\mu \mathrm{g} / \mathrm{l}$ & $\mu \mathrm{g} / \mathrm{l}$ & $\mu \mathrm{g} / \mathrm{l}$ & $\mu \mathrm{g} / \mathrm{l}$ & $\mu g / l$ & $\mu g / l$ & $\mu g / l$ & $\mathrm{mg} / \mathrm{l}$ & $\mathrm{mg} / \mathrm{l}$ & $\mathrm{mg} / \mathrm{l}$ \\
\hline \multirow{5}{*}{$\begin{array}{l}\text { Yağışı Dö- } \\
\text { nem }\end{array}$} & Duraliler 1 & $<4,00$ & $<2,00$ & $<5,00$ & $<1,00$ & $<0,50$ & $<1,00$ & $<4,00$ & 4,02 & 90,79 & 3,7 & $<1,00$ & $<0,50$ & 11,73 & $<0,10$ \\
\hline & Duraliler 2 & $<4,00$ & $<2,00$ & $<5,00$ & $<1,00$ & $<0,50$ & $<1,00$ & $<4,00$ & 4,08 & 94,52 & 3,05 & $<1,00$ & $<0,50$ & 11,7 & $<0,10$ \\
\hline & Boğaçay & $<4,00$ & $<2,00$ & $<5,00$ & $<1,00$ & $<0,50$ & $<1,00$ & $<4,00$ & $<2,00$ & 72,82 & 4,42 & 1,73 & $<0,50$ & 9,85 & $<0,10$ \\
\hline & Yeniköy & $<4,00$ & $<2,00$ & $<5,00$ & $<1,00$ & $<0,50$ & $<1,00$ & $<4,00$ & 6,59 & 115,76 & $<2,00$ & 1,22 & $<0,50$ & 1,95 & $<0,10$ \\
\hline & Yeşilbayır & $<4,00$ & $<2,00$ & $<5,00$ & $<1,00$ & $<0,50$ & $<1,00$ & $<4,00$ & 7,91 & 160,36 & $<2,00$ & 6,52 & $<0,50$ & 1,67 & $<0,10$ \\
\hline \multirow{5}{*}{$\begin{array}{l}\text { Kurak Dö- } \\
\text { nem }\end{array}$} & Duraliler 1 & $<4,00$ & $<2,00$ & $<5,00$ & $<1,00$ & $<0,50$ & $<1,00$ & $<4,00$ & 4,04 & 53,24 & 2,98 & $<1,00$ & $<0,50$ & 12,25 & $<0,10$ \\
\hline & Duraliler 2 & $<4,00$ & $<2,00$ & $<5,00$ & $<1,00$ & $<0,50$ & $<1,00$ & $<4,00$ & 4,26 & 55,97 & 3 & $<1,00$ & $<0,50$ & 11,78 & $<0,10$ \\
\hline & Boğaçay & 11,61 & $<2,00$ & $<5,00$ & $<1,00$ & $<0,50$ & $<1,00$ & $<4,00$ & $<2,00$ & 58,34 & 4,73 & 1,84 & $<0,50$ & 10,88 & $<0,10$ \\
\hline & Yeniköy & 6,4 & $<2,00$ & $<5,00$ & $<1,00$ & $<0,50$ & $<1,00$ & $<4,00$ & 8,72 & 83,54 & $<2,00$ & 1,46 & $<0,50$ & 2,34 & $<0,10$ \\
\hline & Yeşilbayır & $<4,00$ & $<2,00$ & $<5,00$ & $<1,00$ & $<0,50$ & $<1,00$ & $<4,00$ & 8,74 & 91,02 & $<2,00$ & 1,75 & $<0,50$ & 2,54 & $<0,10$ \\
\hline \multirow{2}{*}{$\begin{array}{c}\text { Yönetmelik } \\
\text { Sınır De- } \\
\text { ğerleri } \\
\text { (mg/L) }\end{array}$} & $\begin{array}{l}\text { TS-266 } \\
(2005)\end{array}$ & 0,20 & 0,05 & 2 & 0,01 & 0,001 & 0,005 & 0,01 & 0,01 & 0,2 & 0,05 & 0.02 & 0,5 & 50 & 0,50 \\
\hline & $\begin{array}{l}\text { WHO } \\
\text { (2011) }\end{array}$ & 0,20 & 0,4 & 2 & 0,01 & & & & 0,01 & & 0,05 & 0,07 & 3 & 50 & \\
\hline
\end{tabular}

Şekil 7'de verilmiş olan Schoeller içilebilirlik diyagramı suların sodyum, klor ve sülfat iyon miktarları ile birlikte elektriksel iletkenlik ve sertlik değerlerini dikkate alarak içilebilirlik durumunu göstermektedir. Su örneklerinin analiz ve ölçüm sonuçları kullanılarak hazırlanan diyagramda görüldüğü gibi su örneklerinin tamamı 'İçilebilir Sular' sınıfında yer almakta olup, suların kalitesi iyi kaliteli sular sınıfına girmektedir. 


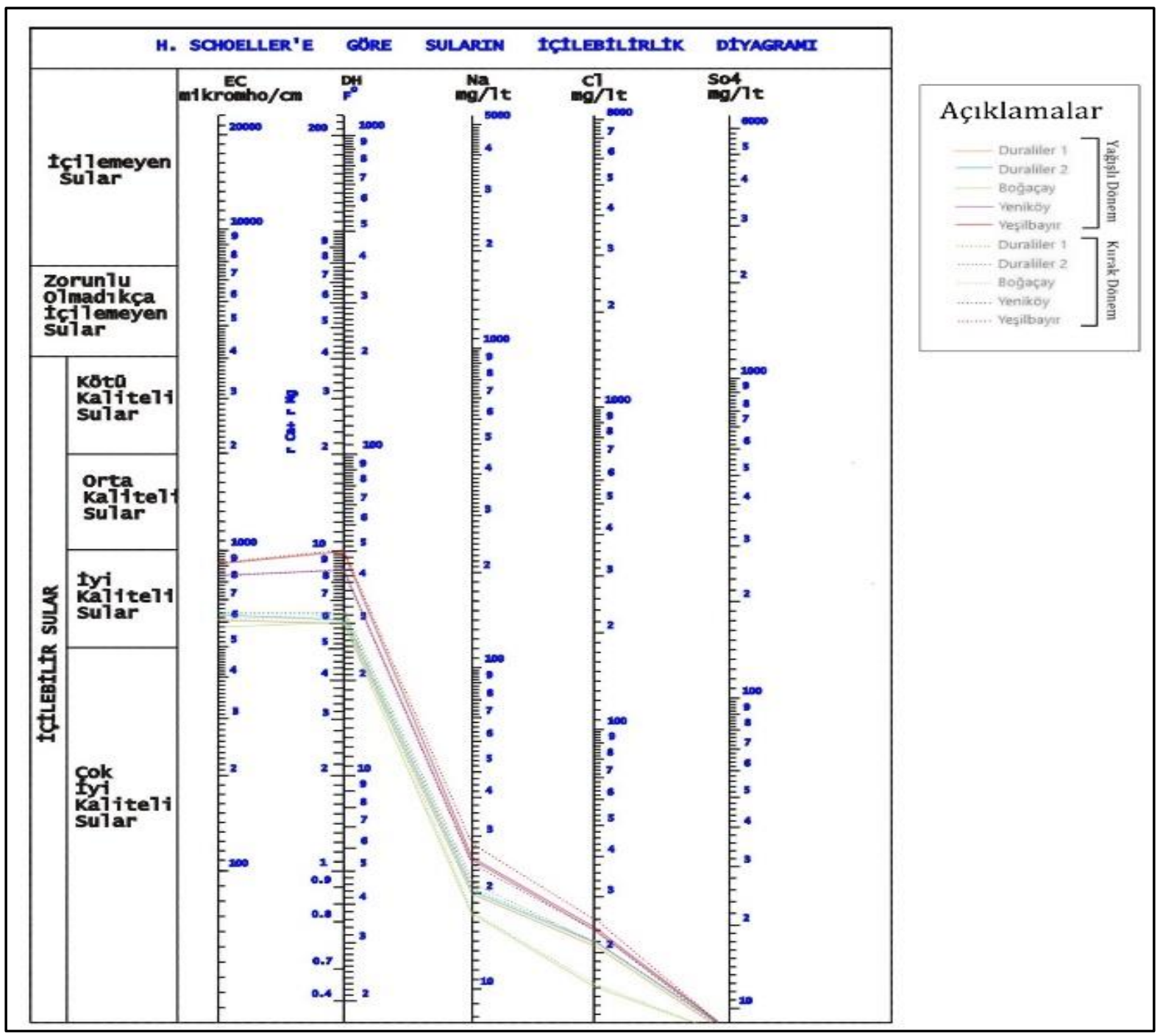

Şekil 7. Schoeller içilebilirlik diyagramı (Mayıs / yağışlı ve Ekim / kurak-2020)

\section{Suların sulama suyu olarak kullanılabilirliği}

Çalışma kapsamında incelenen sular, aynı zamanda bölgede yürütülen tarımsal faaliyetlerde sulama suyu olarak kullanılmaktadır. Bu nedenle, suların sulamada kullanılabilirliğinin değerlendirilebilmesi için su örneklerinin Sodyum iyon yüzdesi (\%Na), Sodyum Adsorbsiyon Oranı (SAR), Özgül Elektriksel İletkenlik (EC), Artıksal Sodyum Karbonat (RSC), Magnezyum Tehlikesi (MT), Geçirgenlik İndeksi $(\mathrm{PI})$ ve Kelley İndeksi $(\mathrm{KI})$ değerleri hesaplanmıştır. Ayrıca, Wilcox ve ABD Tuzluluk Laboratuvarı Diyagramları kullanılarak suların sulamada kullanılabilirliği belirlenmiştir. Çalışma alanındaki suların sulama suyu olarak kullanım özellikleri bakımından, \% $\mathrm{Na}$ değerleri 10.49-12.46 arasında; SAR değerleri 0.43 0.53 arasında değişmektedir. \%Na'a göre suların tamamı "çok iyi" sulama suyu sınıfında, SAR değerine göre ise "çok iyi özellikte sulama suları" sınıfında yer almaktadır. Çalışma alanındaki suların özgül elektriksel iletkenlik değerleri 586-905 $\mu \mathrm{S} / \mathrm{cm}$ arasında değişmektedir. Buna göre Duraliler 1, Duraliler 2 ve Boğaçay istasyonuna ait sular "orta tuzlu sular" sınıfında olup, yıkama suyu olarak kullanılabilir. Ancak Yeniköy ve Yeşilbayır depolarına ait sular "yüksek tuzlu sular" sınıfındadır ve tuza dayanıklı bitki yetiştirmede kullanılabilir. İncelenen su örneklerinin RSC değerleri -3,42 ile 1,42 meq/l arasında değişmektedir. Duraliler 1 istasyonu kurak döneme ait RSC değeri ile Duraliler 2 istasyonundan alınan kurak ve yağışı dönem RSC değerleri "süpheli" sulama suyu sınıfında yer almaktadır. Bunların dışındaki tüm istasyon RSC değerleri "iyi" sulama suyu sınıfında yer almaktadır (Richards 1954). Su örnekleri için hesaplanmış olan PI değerleri \%34,14 ile \% 51,73 arasındadır. Bu değerlere göre suların "iyi" sulama suyu sınıfında olduğu 
belirlenmiştir (Bektaş, 2021). Çalışma alanındaki su örneklerine ait analiz sonuçları kullanılarak hesaplanan MT değerleri \% 25.05 - \% 45,25 arasında değişirken KI değerleri 0,11-0,14 mek/l arasında değişmektedir. Hesaplanan $\mathrm{MT}$ ve $\mathrm{KI}$ değerlerine göre çalışma alanındaki sular sulama suyu olarak kullanıma 'uygun' sular olarak belirlenmiştir (Kelley, 1963; Raghunath, 1987; Bektaş, 2021).

ABD Tuzluluk Laboratuvarı tarafından önerilen sınıflandırmada sular, sodyum adsorbsiyon oranı (SAR) ve özgül elektriksel iletkenlik (EC) değerleri göz önüne alınarak sınıflandırılmaktadır.

Şekil 8'de verilmiş olan ABD Tuzluluk Laboratuvarı diyagramına göre sular 'C2S1' ve 'C3S1' sınıfında yeralmaktadır. Sulama suyu sınıflamasında 'C2S1' sınıfı orta

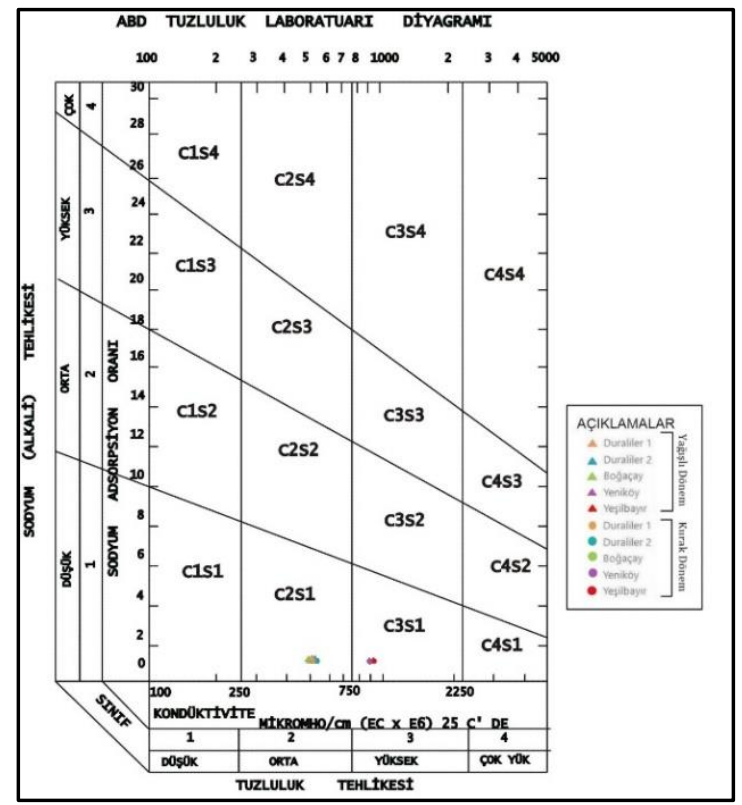

Şekil 8. ABD tuzluluk laboratuvarı diyagramı (Mayıs/yağışı ve Ekim/kurak-2020)

\section{Sağlık Risk Değerlendirmesi}

Insan sağlığı için en önemli unsurlardan biri olan içme suyunun fiziksel ve kimyasal özellikleri ile içerdiği tüm bileşik / element ve miktarları ulusal ve uluslararası birçok yönetmelik ile sınırlandırılmıştır. Bu şekilde İçme suyu kullanılabilirliğine yönelik belirlenen parametreler ve limit tuzlulukta ve az sodyumlu suları tanımlarken 'C3S1' SInıfı sodyuma karşı duyarlı olan bitkiler dışında her türlü tarım için uygun özellikte olması ile birlikte fazla tuzlu su özelliğinde olduğu için tuzlu yüzeyaltı suyunun bir kısmını uzaklaştırarak kabul edilebilir güvenli tuz birikim alanına iletecek açık veya borulu drenaj yapılmaksızın bitkiler için kullanılamayacak suları işaret etmektedir. Çalışma alanında Duraliler 1, Duraliler 2 ve Boğaçay'ı temsil eden sular 'C2S1' sınıfında, Yeniköy ve Yeşilbayır depolarını temsil eden sular ise 'C3S1' sınıfında yer almaktadır. Buna göre, Yeniköy ve Yeşilbayır depolarından alınan suların sulama suyu amacıyla dikkatli kullanılması gerekliliğini göstermektedir. Şekil 9'da verilmiş olan Wilcox diyagramı ise suların \% Na ve EC değerlerini dikkate alarak hazırlanmış ve sonuç olarak çalışma alanındaki suların 'çok iyi kullanılabilir sular' sınıfında yer aldığı belirlenmiştir.

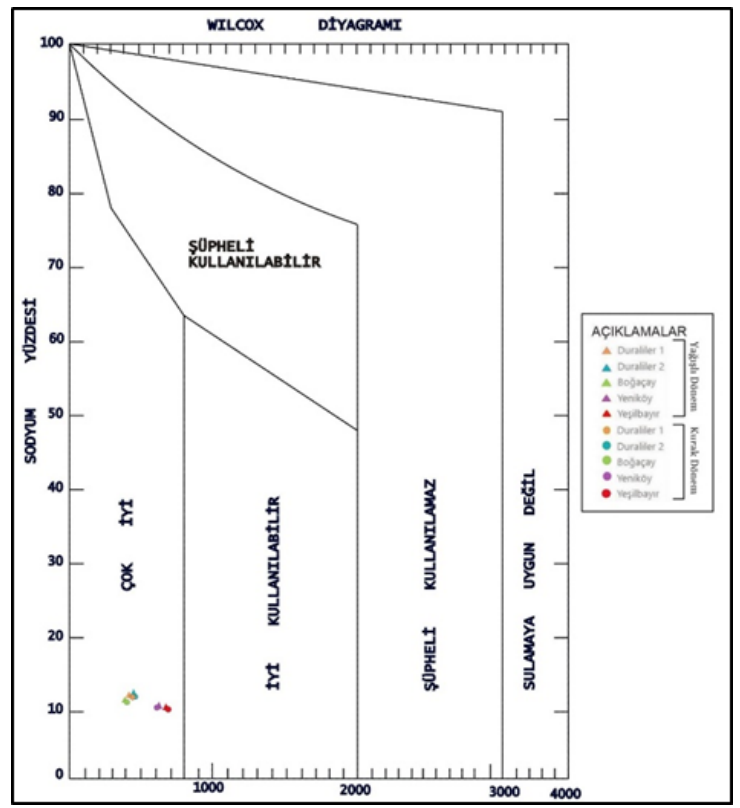

Şekil 9. Wilcox diyagramı (Mayıs / yağışı ve Ekim / kurak-2020)

değerler dikkate alınarak suların kontrollerini gerçekleştirmek mümkün olmaktadır (Varol ve ark., 2021). İçme suyu olarak kullanılacak sularda arsenik için müsaade edilen limit değer $10 \mu \mathrm{g} / \mathrm{L}$ olarak belirtilmektedir (TS-266 2005; WHO 2011). Çalışma kapsamında incelenen su örneklerinin As konsantrasyonları <2 $\mu \mathrm{g} / \mathrm{l}$ ile 8,74 $\mu \mathrm{g} / \mathrm{l}$ arasında değişmektedir (Tablo 5). 
Antalya İli İçme Suyu Kaynaklarının Hidrojeokimyasal Özellikleri ve Sağlık Risk Değerlendirmesi

Tablo 5. İçme suyu örneklerinin As analiz sonuçları

\begin{tabular}{|c|c|c|}
\hline \multicolumn{2}{|r|}{ Örnek } & Arsenik $(\mu \mathrm{g} / \mathrm{l})$ \\
\hline \multirow{5}{*}{ 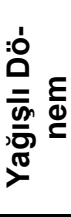 } & Duraliler-1 & 4.0200 \\
\hline & Duraliler-2 & 4.0800 \\
\hline & Boğaçay & $<2$ \\
\hline & Yeniköy-Depo & 6.5900 \\
\hline & Yeşilbayır-Depo & 7.9100 \\
\hline \multirow{5}{*}{ 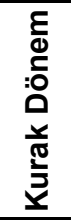 } & Duraliler-1 & 4.0400 \\
\hline & Duraliler-2 & 4.2600 \\
\hline & Boğaçay & $<2$ \\
\hline & Yeniköy-Depo & 8.7200 \\
\hline & Yeşilbayır-Depo & 8.7400 \\
\hline
\end{tabular}

Suların bölge halkı tarafından tüketilmesi halinde insan sağlığına etkilerini belirlemek için USEPA tarafından geliştirilen "Sağlık riski değerlendirme yöntemi" kullanılmıştır. Yapılan hesaplamalar çocuk ve yetişkinler için ayrı ayrı yapılmış olup hesaplamalarda kabul edilen referans değerler Tablo 6'da verilmiştir.

Tablo 6. Hesaplamalarda kabul edilen referans değerler

\begin{tabular}{cccccccc}
\hline & $\begin{array}{c}\text { L } \\
\text { (l/gün) }\end{array}$ & $\begin{array}{c}\text { EF } \\
\text { (gün/yıl) }\end{array}$ & $\begin{array}{c}\text { ED } \\
\text { (yıl) }\end{array}$ & $\begin{array}{c}\text { AT } \\
\text { (gün- } \\
\text { lük) }\end{array}$ & $\begin{array}{c}\text { BW } \\
\text { (kg) }\end{array}$ & $\begin{array}{c}\text { RfD } \\
\text { (mg/kg/gün) }\end{array}$ & $\begin{array}{c}\text { SF } \\
\text { (mg/kg/gün) }\end{array}$ \\
\hline Yetişkin & 2 & 365 & 30 & 10950 & 70 & 0.0003 & 1.5 \\
\hline Çocuk & 1 & 365 & 6 & 2190 & 15 & 0.0003 & 1.5 \\
\hline
\end{tabular}

Çalışma kapsamında incelenen su örneklerinin As bakımından insan sağlığı üzerindeki kanserojen olmayan tehlike katsayıları (HQ) ve Kanser Riski (Rc) değerleri Tablo 7'de verilmiştir. Elde edilen verilere göre su örneklerinin tamamının yetişkinler için $\mathrm{HQ}$ değeri 1'den küçüktür.

Çocuklar için ise tehlike katsayısı değerleri Yeniköydepo ve Yeşilbayır-depodan yağışı ve kurak dönemde alınan su örneklerinde 1 'den büyük olup kanserojen olmayan etkiler bakımından dikkat edilmesi gerektiğini göstermektedir. Aynı şekilde Rc değerleri de kabul edilebilir veya tolere edilebilir risk değerlerinin (10-6 ile
10-4 arası) sınırında kalmaktadır. Bu değerlere göre çaıışma alanında içme suyu olarak kullanılan suların, insan sağlığı açısından ciddi boyutta risk taşımadığı söylenebilir. Ancak depolardan alınan suların As içerikleri kısmen yüksektir ve bu suların çocuklar tarafından tüketilmesi önerilmemektedir. Bu konuda, su kalitesi izleme ve kontrolleri titizlikle yapılmalı ve sınır değerin $(10 \mu \mathrm{g} / \mathrm{l})$ aşılması durumunda sular içme suyu olarak kullanılmamalıdır. 
Antalya İli İçme Suyu Kaynaklarının Hidrojeokimyasal Özellikleri ve Sağlık Risk Değerlendirmesi

Tablo 7. Arsenik için ADD, Rc ve $H Q$ değerleri

\begin{tabular}{|c|c|c|c|c|c|c|c|}
\hline \multirow{2}{*}{\multicolumn{2}{|c|}{\begin{tabular}{|l|} 
Örnek \\
\end{tabular}}} & \multicolumn{3}{|c|}{ Yetişkin } & \multicolumn{3}{|c|}{ Çocuk } \\
\hline & & \multirow{2}{*}{\begin{tabular}{|l} 
ADD \\
0.0001
\end{tabular}} & \multirow{2}{*}{$\begin{array}{c}\text { Rc } \\
0.0002\end{array}$} & \multirow{2}{*}{\begin{tabular}{|c|}
$\mathbf{H Q}$ \\
0.3829 \\
\end{tabular}} & \multirow{2}{*}{$\begin{array}{c}\text { ADD } \\
0.0003\end{array}$} & \multirow{2}{*}{\begin{tabular}{|c|}
$\mathbf{R c}$ \\
0.0004 \\
\end{tabular}} & \multirow{2}{*}{\begin{tabular}{|c|}
$\mathbf{H Q}$ \\
0.8933 \\
\end{tabular}} \\
\hline \multirow{5}{*}{ 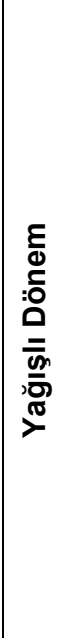 } & $\begin{array}{l}\text { Durali- } \\
\text { ler-1 }\end{array}$ & & & & & & \\
\hline & $\begin{array}{l}\text { Durali- } \\
\text { ler-2 }\end{array}$ & 0.0001 & 0.0002 & 0.3886 & 0.0003 & 0.0004 & 0.9067 \\
\hline & $\begin{array}{l}\text { Boğa- } \\
\text { çay }\end{array}$ & 0.0001 & 0.0001 & 0.1905 & 0.0001 & 0.0002 & 0.4444 \\
\hline & $\begin{array}{l}\text { Yeni- } \\
\text { köy- } \\
\text { Depo }\end{array}$ & 0.0002 & 0.0003 & 0.6276 & 0.0004 & 0.0007 & 1.4644 \\
\hline & $\begin{array}{l}\text { Yeşil- } \\
\text { bayır- } \\
\text { Depo }\end{array}$ & 0.0002 & 0.0003 & 0.7533 & 0.0005 & 0.0008 & 1.7578 \\
\hline \multirow{5}{*}{ 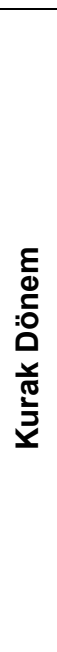 } & $\begin{array}{l}\text { Durali- } \\
\text { ler-1 }\end{array}$ & 0.0001 & 0.0002 & 0.3848 & 0.0003 & 0.0004 & 0.8978 \\
\hline & $\begin{array}{l}\text { Durali- } \\
\text { ler-2 }\end{array}$ & 0.0001 & 0.0002 & 0.4057 & 0.0003 & 0.0004 & 0.9467 \\
\hline & $\begin{array}{l}\text { Boğa- } \\
\text { çay }\end{array}$ & 0.0001 & 0.0001 & 0.1905 & 0.0001 & 0.0002 & 0.4444 \\
\hline & $\begin{array}{l}\text { Yeni- } \\
\text { köy- } \\
\text { Depo }\end{array}$ & 0.0002 & 0.0004 & 0.8305 & 0.0006 & 0.0009 & 1.9378 \\
\hline & $\begin{array}{l}\text { Yeşil- } \\
\text { bayır- } \\
\text { Depo }\end{array}$ & 0.0002 & 0.0004 & 0.8324 & 0.0006 & 0.0009 & 1.9422 \\
\hline
\end{tabular}

\section{SONUÇLAR}

Bu çalışmada, Antalya ili içme suyu kaynaklarının hidrojeokimyasal özellikleri incelenmiş su kaynaklarının sağlık risk değerlendirmesi yapılmış ve insan sağlığına etkisi ortaya konulmuştur. Bu kapsamda, yapılan çalışmalar sonucunda çalışma alanında yer alan jeolojik birimler litolojik özelliklerine ve yeraltısuyu bulundurma kapasitelerine göre Taneli Ortam Akiferi, Karstik Akifer, Yarı Geçirimli Birim ve Geçirimsiz Birim olarak 4 akifer grubu tanımlanmıştır. Çalışma alanındaki suların jeolojik birimlerle olan ilişkileri ortaya konmuş ve su örneklerinin tamamı $\mathrm{Ca}-\mathrm{CO}_{3}$ ve $\mathrm{Ca}-\mathrm{Mg}-\mathrm{HCO}_{3}$ 'lü sular sınıfında olduğu belirlenmiştir.
Su örneklerinin içme suyu olarak kullanım özelliklerini belirlemek amacıyla TS-266 (2005) ve WHO (2011) yönetmelikleri tarafından belirtilen limit değerleri ile analiz sonuçları karşılaştırılmıştır. Buna göre, su örneklerinin tamamının TS-266 (2005) içme suyu limit değerlerine uygun ve içilebilir özellikte olduğu belirlenmiştir. Ancak, Yeniköy ve Yeşilbayır depolardan alınan örneklerin $\mathrm{HCO}_{3}$ konsantrasyonlarının ve Yeşilbayır deposundan alınan örneklerin ise TDS değerlerinin WHO (2011) limit değerlerini aştığı belirlenmiştir. Çalışma alanındaki suların sulama suyu olarak kullanım özellikleri bakımından genel olarak uygun ve iyi sulama suyu sınıfında olduğu belirlenmiştir. 
Çalışma alanında içme suyu olarak kullanılan suların bünyesinde bulundurabilecekleri bileşiklerin miktarı, insan sağlığı için müsaade edilebilecek limit değerler ile karşılaştırılmıştır. Çalışma alanındaki suların As bakımından insan sağlığı üzerindeki kanserojen olmayan tehlike katsayıları (HQ) yetişkinler için 1'den küçük olup kullanılmasında bir sakınca yoktur. Ancak çocuklar için tehlike katsayısı değerleri Yeniköy-depo ve Yeşilbayırdepodan alınan su örneklerinin $\mathrm{HQ}$ değerlerinin 1'den büyük olduğu ve kanserojen olmayan etkiler bakımından dikkat edilmesi gerektiği sonucu çıkarılmaktadır. Bu değerlere göre çalışma alanında içme suyu olarak kullanılan suların, insan sağlığı açısından ciddi boyutta risk taşımadığı söylenebilir. Ancak depolardan alınan suların As içerikleri kısmen yüksek olup, bu suların çocuklar tarafından tüketilmesi önerilmemektedir.

\section{TEŞEKKÜR}

Çalışmada kullanılan su kimyası verilerini sağlayan Antalya Su ve Atıksu İdaresi (ASAT) Genel Müdürlüğü'ne teşekkür ederiz. Ayrıca bu çalışma, Süleyman Demirel Üniversitesi Fen Bilimleri Enstitüsü Jeoloji Mühendisliği Anabilim Dalında yapılan yüksek lisans tez çalışmasının bir ürünüdür.

\section{KAYNAKLAR}

Akay, E., Uysal Ş. (1985). Orta Toros Dağlarının Batısındaki (Antalya) Neojen Çökellerinin Stratigrafisi, Sedimantolojisi ve Yapısal Jeolojisi. MTA Raporu. No. 7799, Ankara

Amiri, V., Kamrani, S., Ahmad, A., Bhattacharya, P., Mansoori, J. (2021). Groundwater quality evaluation using Shannon information theory and human health risk assessment in Yazd province, central plateau of Iran. Environmental Science and Pollution Research, 28(1): 1108-1130.

Bektaş, S. (2021). Antalya İli İçme Suyu Kaynaklarının Hidrojeokimyasal Özellikleri ve Sağlık Risk Değerlendirmesi. Yüksek Lisans Tezi (yayımlanmamış), Süleyman Demirel Üniversitesi Fen Bilimleri Enstitüsü, Isparta.

Boateng T.K., Opoku F., Akoto, O. (2019). Heavy metal contamination assessment of groundwater quality: a case study of Oti landfill site, Kumasi. Applied Water Science, 9(2): 33.

DSI (2017a). 9-16 Antalya-Çakirlar-Boğaçay Yeraltisuyu Alt Havzasi Hidrojeolojik Etüt Raporu, Devlet Su İşleri 13. Bölge Müdürlüğü, Antalya

DSi (2017b). 9-17 Antalya-Merkez Yeraltisuyu Alt Havzasi Hidrojeolojik Etüt Ara Raporu, Devlet Su İşleri 13. Bölge Müdürlüğü, Antalya.

Gibbs, R. (1970). Mechanism Controlling World River Water Chemistry. Science, 170: 1088-1090.

Günay Y., Bölükbaşı A.S., Yoldemir O. (1982). Beydağlarının Stratigrafisi ve Yapısı, Türkiye Altıncı Petrol Kongresi Tebliğleri. Ankara, 90-101.

IRIS (2005). US Environmental Protection Agency. Integrated Risk Information System. Cincinnati, $\mathrm{OH}$.
Ji, Y., Wu, J., Wang, Y., Elumalai, V., Subramani, T. (2020). Seasonal variation of drinking water quality and human health risk assessment in Hancheng City of Guanzhong Plain, China. Exposure and Health, 12(3): 469-485.

Kalafatçıoğlu, A. (1973). Antalya Körfezi Batı Kısmının Jeolojisi. MTA Dergisi, 81: 82-131.

Karagüzel, R., Davraz, A., Soyaslan, İ., Seyman, F., Şener, Ş., Şener, E. (2006). Antalya İçmesuyu Havzalarının Kirlilik Tehditi Açısından Değerlendirilmesi, Antalya İçmesuyu ve Sorunları Sempozyumu, Akdeniz Üniversitesi, 15-16 Haziran, 113-120.

Kelley, W. P. (1940). Permissible Composition and Concentration of Irrigation Water. In Proceedings of the American Society of Civil Engineers. 66:607-613.

Kelley, W. P. (1963). Use of saline irrigation water. Soil science, 95(6): 385-391.

Koçak, İ., Arıbaş, K. (2003). Akkoç Polyesi (Antalya). Türk Coğrafya Dergisi, 41:77-96.

Li, S., Zhang, Q. (2010). Risk assessment and seasonal variations of dissolved trace elements and heavy metals in the Upper Han River, China. Journal of Hazardous Materials, 181:1051-1058.

Özüş, A. S. (1992). Antalya Traverten Platosunun Jeolojik, Hidrolojik, Hidrojeolojik ve Hidrokimyasal Özelliklerinin İncelenmesi. Doktora Tezi (yayımlanmamış), Çukurova Üniversitesi Fen Bilimleri Enstitüsü, Adana.

Poisson, A. (1977). Recherches Geologique Dans Les Taurides Occidentales (Turquie). These University Paris- Sud, 795 pg, Orsay.

Raghunath, H.M. (1987). Groundwater. $2^{\text {nd }}$ ed. Wiley Eastern Ltd, New Delhi.

Resmi Gazete (2019). İçmesuyu Temin Edilen Suların Kalitesi ve Arıtılması Hakkında Yönetmelik. Resmi Gazete No: 30823.

Richards, L.A. (1954). Diagnosis and improvement of saline and alkali soils. USDA Agricultural Handbook No. 60. US Department of Agriculture, Washington DC.

Schoeller, H., (1955). Gechemie Des Eaux Souterranes. Review Instutie Franc. Petrole, 3-4, Paris.

Sohrabi, N., Kalantari, N., Amiri, V., Saha, N., Berndtsson, R., Bhattacharya, P., Ahmad, A. (2021). A probabilistic-deterministic analysis of human health risk related to the exposure to potentially toxic elements in groundwater of Urmia coastal aquifer (NW of Iran) with a special focus on arsenic speciation and temporal variation. Stochastic Environmental Research and Risk Assessment, 35(7): 1509-1528.

Şenel, M., H., Bilgin, Z.R., Şen, A.M., Karaman, T., Dinçer, M.A., Durukan, E., Arbas, A., Örçen, S., Bilgi, C. (1989). Çameli (Denizli)-Yeşilova (Burdur)-Elmalı (Antalya) ve Kuzeyinin Jeolojisi. Maden Tetkik Ve Arama Genel Müdürlüğü Rapor No: 9761, Ankara (yayımlanmamış).

Şenel, M. (1997a). 1/100.000 ölçekli Türkiye Jeoloji Haritaları, Antalya O25 paftası. MTA Genel Müdürlüğü, jeoloji Etütleri Dairesi yayını, Ankara.

Şenel, M. (1997b). 1/100.000 ölçekli Türkiye Jeoloji Haritaları, Antalya O24 paftası. MTA Genel Müdürlüğü, jeoloji Etütleri Dairesi yayını, Ankara.

Şenel, M. (1997 c). 1/100.000 ölçekli Türkiye Jeoloji Haritaları, Antalya N24 paftası. MTA Genel Müdürlüğü, jeoloji Etütleri Dairesi yayını, Ankara. 
TS-266 (2005). Sular - İnsani Tüketim Amaçlı Sular, TSE 1. Baskı, Ankara.

URL-1 (2021). https://www.asat.gov.tr/tr/su_kalite.html (Erişim Tarihi: 10.06.2021)

USEPA (1986). Guidelines for Carcinogen Risk Assessment. U.S. Environmental Protection Agency, EPA/600/8-87/045, Washington DC, USA.

USEPA, (1989). Risk Assessment Guidance for Superfund. Vol. I. Human Health Evaluation Manual. Part A. Interim Final, Office of Emergency and Remedial Response, U. S. Environmental Protection Agency, Washington, DC, USA.

USEPA (2001). Risk Assessment Guidance for Superfund, Volume 1: Human Health Evaluation Manual (Part E, Supplement Guidance for Dermal Risk Assessment). Office of Emergency and Remedial Response, Washington, DC, USA.

USEPA (2004). Risk Assessment Guidance for Superfund Volume I: Human Health Evaluation Manual (Part E, Supplemental Guidance for Dermal Risk Assessment) Final. EPA/540/R/99/005 OSWER 9285.7-02EP PB99-963312 July 2004, Office of Superfund Remediation and Technology Innovation U.S. Environmental Protection Agency Washington, DC, USA.

USEPA (2005). Guidelines for Carcinogen Risk Assessment. EPA/630/P-03/001F. US Environmental Protection Agency, Risk Assessment Forum, Washington, DC, USA.
Ustaoğlu, F., Taş, B., Tepe, Y., Topaldemir, H. (2021). Comprehensive assessment of water quality and associated health risk by using physicochemical quality indices and multivariate analysis in Terme River, Turkey. Environmental Science and Pollution Research, DOI: 10.1007/s11356-021-15135-3

Varol, S., Şener, Ş., Şener, E., (2021). Assessment of groundwater quality and human health risk related to arsenic using index methods and GIS: A case of Şuhut Plain (Afyonkarahisar/Turkey). Environmental Research, 202; DOI: https://doi.org/10.1016/j.envres.2021.111623.

WHO (2011). World Health Organisation Guidelines for Drinking-water Quality, Third Edition, Incorporating The First and Second Addenda, WHO Publication, Geneva, 668 p.

Wilcox, L.V. (1955). Classification and Use of Irrigation Waters, US Dept. Agriculture Circular, Washington.

Yalçınkaya, S., Engin, A., Taner, K., Afşar, Ö.P., Dalkılıç, H., Özgönül, E. (1986). Batı Torosların jeolojisi. Maden Tetkik ve Arama Genel Müdürlüğü Raporu 7898, (yayımlanmamış).

Zhang, Q., Xu, P., Qian, H., (2020). Groundwater quality assessment using improved water quality index (WQI) and human health risk (HHR) evaluation in a semi-arid region of northwest China. Exposure and Health, 12:487-500. 